Preprint: accepted version appears as:

CJ Vincent, A Blandford (2017) How do health service professionals consider human factors when purchasing interactive medical devices? A qualitative interview study. Applied Ergonomics 59, 114-122

http://dx.doi.org/10.1016/j.apergo.2016.08.025

\title{
How do health service professionals consider human factors when purchasing interactive medical devices? A qualitative interview study
}

CJ Vincent \& A Blandford

\begin{abstract}
We present findings of a UK study into how those involved in purchasing interactive medical devices go about evaluating usability, the challenges that arise, and opportunities for improvement. The study focused on procurement of infusion devices because these are used by various professionals across healthcare. A semi-structured interview study was carried out involving a range of stakeholders (20 in total) involved in or impacted by medical device procurement. Data was analysed using thematic analysis, a qualitative method designed to support the identification, analysis and reporting of patterns. In principle, health service purchasing was found to accommodate consideration of equipment usability. In practice, the evaluation process was driven primarily by engineering standards; assessment of local needs did not accommodate substantive assessment of usability; and choice was limited by the availability of equipment on the marketplace. We discuss ways in which purchasing could be improved through techniques that account for social circumstances.
\end{abstract}

Keywords: Interface, User Computer; Purchasing; Medical Device Design.

\section{Highlights}

- Purchasing provides an opportunity to shape the usability of medical devices.

- In the purchasing processes studied, the assessment of usability was limited.

- The processes studied emphasised functional requirements.

- We identify tools that can account for broader (social) circumstances. 


\section{Introduction}

Poor usability is frequently cited as a contributory factor in incidents involving medical devices (AAMI/FDA, 2010). There are many potential sources of pressure for delivering products with acceptable usability, including regulatory requirements, international standards, and the needs of the market.

The decision about procurement of a medical device is a key point in shaping usability, both directly and indirectly. Firstly, the local procurement decision will affect staff and patient experience as the selected devices are typically used for several years. Secondly, feedback about user requirements has the longer-term potential to inform manufacturers about user needs and to raise the importance of usability within the development process. To better understand how usability does and could feature within procurement processes, we need to better understand how purchasing really happens, how equipment usability is assessed within that process, and what tools might help to support usability assessment within procurement. This paper reports on a UK study investigating how those involved in purchasing evaluate the usability of medical equipment, the challenges that arise and opportunities for improvement.

We focus on how those involved in the selection of infusion devices (volumetric pumps and syringe drivers) reason about equipment usability. ISO standards define usability as effectiveness, efficiency and user satisfaction (IEC, 2015); however, for this study we did not work with any a priori definition of usability. We worked with those involved in purchasing as they are aware of the stakeholders involved and are familiar with how equipment is evaluated. Whether or not they had a background in HF / HCI, we sought to better understand their views on usability and how they take this into account in procurement.

The focus on volumetric pumps and syringe drivers was chosen as infusion devices are widely used for the administration of medication, fluids and nutrition, across a range of both hospital and home contexts, by a diverse range of users. Since most organisations aim to standardise their equipment of any given type, the procurement of infusion devices is at an extreme of complexity for those involved in the decision.

\section{Background}

It is widely accepted that interactive medical equipment should be usable and fit for purpose (Zhang et al., 2003), but it is also recognised that there are challenges in assessing usability in an organisational setting (Maguire, 2001). For example, although health service staff require decisions based on "the best possible evidence" (Pecchia et al., 2013), the factors that contribute to safety, usability and overall fitness for purpose may be based on opinion, numerous and difficult to scope. The User Interface (UI) is a case in point, as it supports safety critical operations, but the views on fitness and suitability vary, may be conflicting, may be based on only part of the work system and are hard to detach 
from the organisational setting. Improved usability can contribute to the quality of patient and staff experience (Liddell et al., 2008) as well as improving safety, cost, time and reliability (Cassano-Piché et al., 2010; Gandillon, 2013), but we know little about how these improvements can happen in practice and how integration occurs across the different elements of a work system.

In this section, we review key background studies on purchasing and usability: who is typically involved; how usability has previously been used in purchasing; and approaches to considering usability within purchasing.

\section{Who is involved in purchasing}

Others (Hinrichs, 2009; Keselman et al., 2003; Nemeth et al., 2014; Phillips et al., 2007) have provided an overview of the groups involved in purchasing and how they relate to one another. In the UK, infusion devices for general use are often selected by a purchasing committee (e.g., (Freemantle et al., 2011)), working closely with a purchasing department. This committee typically represents a range of interested parties: for example, end users, power users, trainers, pharmacy staff, and those responsible for the management and maintenance of the equipment. In addition, the purchasing department may work with external bodies such as regional or national purchasing groups. A case for procurement might also be made at a national level (e.g., (Phillips et al., 2007)), or as a result of changes to legislation (Ford and Phillips, 2008). In this case a range of law making bodies, standards agencies, government departments, regulators, charities and special interest groups could be involved in defining what is and is not an acceptable solution. An overview of those involved in purchasing is provided in Figure 1.

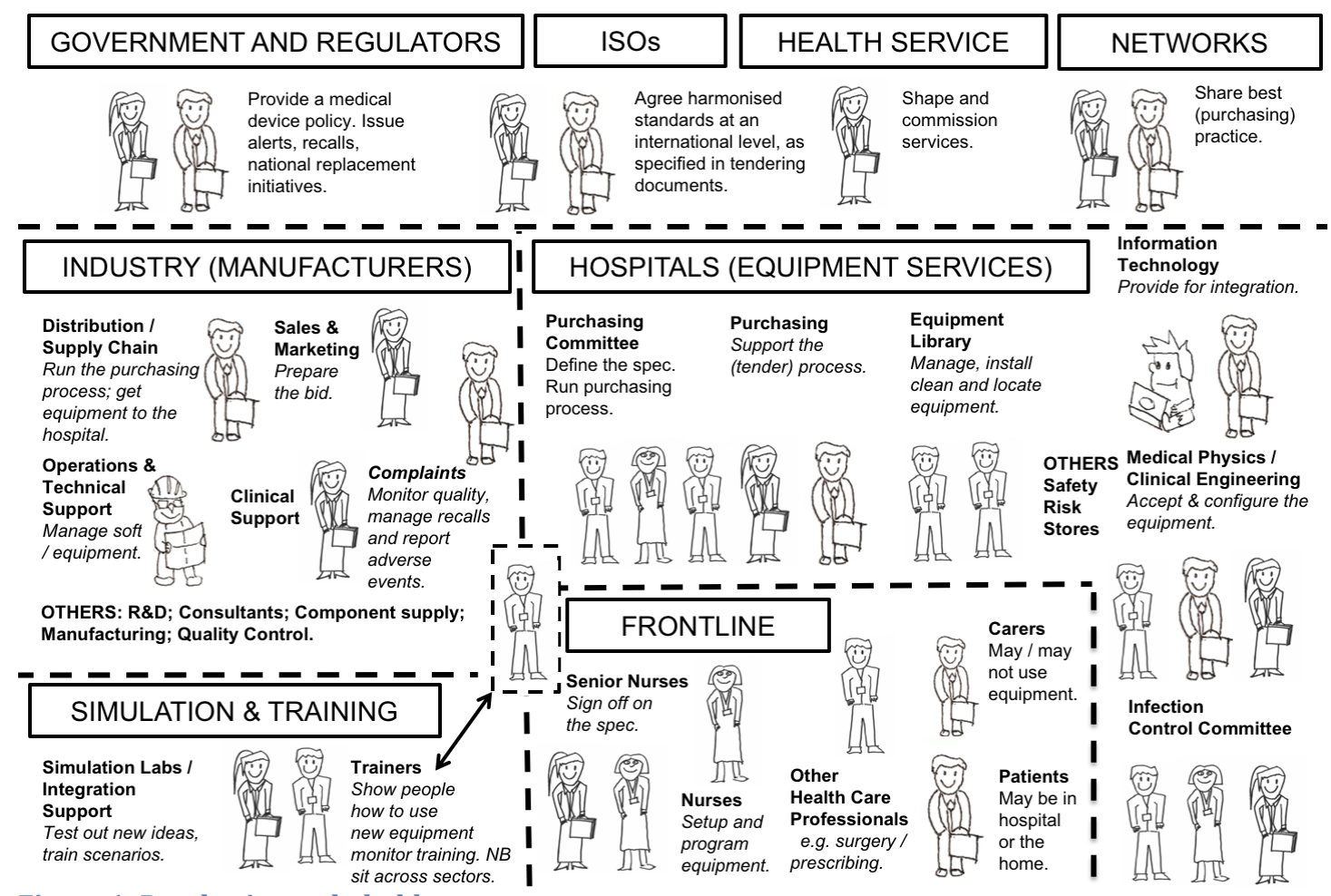

Figure 1: Purchasing stakeholders 
Usability evaluation or Human Factors methods have been applied to scope efforts and reduce buying options (Ginsburg, 2005; Turley et al., 2006; Zhang et al., 2003). They have also been used to collect input from a wide array of stakeholders, support multidisciplinary communication and support reconciliation of viewpoints (Johnson et al., 2005; Keselman et al., 2004; Namshirin et al., 2011). Johnson et al (2005) highlight the variety of those involved, including nurses, doctors, pharmacists, biomedical technicians, quality improvement staff, unit managers, patients, trainers and accountants. This emphasises that the consideration of usability needs to accommodate multiple perspectives and adopt a holistic approach. Namshirin et al (2011) illustrate how a multidisciplinary approach (including usability evaluation) applies to the selection of smart infusion pumps (i.e., pumps with safety features designed to prevent an accidental overdose of medication). They suggest that by involving a range of stakeholders and considering the variety of front line needs, hospitals can choose equipment that implements appropriate safety measures to reduce the potential for drug and dose errors. Although this appears to be a good example of collaborative evaluation, other studies have highlighted some of the challenges in procurement.

One such challenge is that hospitals might not adopt a multidisciplinary approach at all. For example, Trbovich et al. (2011) studied 29 hospitals buying smart pumps in Ontario, Canada, and found that many were not involving multidisciplinary teams. Even if a multidisciplinary approach is adopted, the right people might not be involved. For example, in the US, there have been reports of administrators dominating infusion device purchasing and financial requirements being prioritised over clinical preferences (Nemeth et al., 2009). In a similar study, also based on US practice, Keselman and colleagues (2003) focused on patient safety related requirements and found that although multiple sections of the hospital contributed to the specification and selection process, communication was limited and administrative staff were ultimately responsible for purchasing decisions. These staff tended to equate patient safety with technical aspects rather than device usability or Human Factors. The same study found that expressions of user need were filtered through questionnaires supplied by the manufacturers, passed on to administrators. Gosbee et al. (2001) report on a panel session on usability evaluation in a hospital context which identified issues including there not being the right training in place, a lack of management buy in, limitations in resource and difficulty integrating usability testing with existing purchasing processes. In other cases the assessment of technology has been held up by disagreement amongst clinical professions, and differences in opinion over evaluation methodology (Cook, 2012; Cook et al., 2012; Kinsella, 2013; Kinsella et al., 2012).

These issues are not limited to the hospital context: medical device manufacturers can also face constraints in including Human Factors practice (Money et al., 2011). The situation on the supply side may change following the recent issue of FDA guidance on "Applying Human Factors and Usability Engineering to Optimise Medical Device Design” (FDA, 2016), which focuses on 
design rather than purchasing. This guidance sets out the content of a Human Factors Engineering / Usability Engineering report and outlines techniques that can be applied (e.g., contextual enquiry, interviews, task analysis, heuristic analysis, cognitive walkthrough and simulated use testing) (FDA, 2016). Such a report can be requested as part of a regulatory submission in the US; however it does not give assurance that the assessment will provide balanced consideration of all work elements such as people, organisations, technology, tasks and the environment. The focus of regulatory submissions (across legislatures) is on safety, rather than user experience. Also, tests for safety conducted prior to marketing, based on particular assumptions about use, do not necessarily mean that a device is suitable for a given hospital context (Blandford et al., 2014).

The lack of consideration of equipment usability often leads to problems; for example, newly introduced equipment has resulted in workarounds (Koppel et al., 2008), increases in workload (Patterson et al., 2005; Saleem et al., 2005), a lack of acceptance (Carayon et al., 2010) and the avoidance of safety features (Trbovich et al., 2011). For example, Lee et al. (Lee et al., 2012) analysed log files and found a high incidence of "door open" alarms that could only have resulted from workarounds or violations in practice. Rajkomar and Blandford (2012) observed the use of infusion devices in an Intensive Care Unit (ICU) and found a frequently used function (volume reset) embedded under multiple levels of menu hierarchy: a mismatch between the way the device was designed to be used and local protocols resulted in poor usability. These are examples of misalignments across the work system: the task and technology are at odds with one another.

\section{Approaches to considering equipment usability}

Even if usability evaluation is promoted, it can be hard to realise it in practice. Although there are many methods for studying the intersection between medical technology and practitioner cognition (Schraagen and Verhoeven, 2013), applying usability evaluation rigorously and exhaustively is not straightforward. Usability feedback is often subjective and may sit uncomfortably with broader purchasing processes. When it comes to integrating usability assessment with formalised processes, the current situation reflects other public sector purchasing exercises that prioritise accountability over effectiveness. For example, Pollock and Williams (2007) describe the comparisons made during a software procurement exercise as resulting in a schism between subjective and formal testimonials: decisions based on personal assessments contrasted with the need for a "stabilised form of accountability" where legislative requirements require an objective stance.

A similar account is provided by Hussain and Taylor (2007), who focus on the introduction of information systems within the UK National Health Service. They found a tendency for a functionalist agenda to prevail amongst those responsible for enacting change. This provides a systematic approach to discovering what are seen as stable and objective requirements. It involves a reduced need to engage with stakeholders in lieu of a formal, rationalistic and procedural method. 
A functionalist agenda may be at odds with the need to perform a comprehensive assessment of usability. For example, it generally fits a stable world view and an objectivist approach (generalizable requirements can be discovered and stated precisely), whereas aspects relating to equipment usability may be subjective, unstable and require consideration of multiple aspects of a work system.

Smith and Carayon (1989) propose that to provide a safer and more productive workplace it is important to develop a holistic view of the work system, in terms of interactions between people, technology, tasks, organisations and environment. This has culminated in SEIPS (the Systems Engineering Initiative for Patient Safety), a framework for understanding the structures, processes and outcomes in healthcare (Carayon, 2009; Carayon et al., 2006; Carayon and Smith, 2000; Carayon et al., 2014). Approaches such as SEIPS have been applied to work system design (Carayon et al., 2006) and to evaluating work systems in terms of patient safety (Carayon et al., 2014), but not, to date, to supporting purchasing decisions.

By understanding how purchasing is currently happening in hospitals, we aim to better understand how to consider usability during equipment evaluation and how this type of evaluation can be integrated with existing practice.

\section{Aim and objectives}

The aim of this study was to identify common issues and practices in purchasing based on the experiences of those involved in selecting, buying and using equipment, with a view to identifying ways in which those involved in purchasing can be better informed when reasoning about interactive medical devices (e.g. during assessment and evaluation). A qualitative study was conducted in order to understand purchasing decisions in a rich and nuanced way, with a focus on the usability of infusion devices. This included:

- how purchasing occurs;

- the factors that shape purchasing decisions;

- why decisions are made in the way that they are; and

- perceptions, cultures and values relating to the above.

\section{Methods}

A qualitative interview study involving UK National Health Service (NHS) staff and equipment suppliers was conducted based on the following procedure.

\section{Data gathering}

The study involved semi-structured interviews with 20 participants across 4 hospitals, 1 community service provider, 2 universities and 1 equipment provider (see Table 1). Participants across multiple sites were approached in 
parallel. Interviews focused on building an understanding of practice and identifying opportunities for support. Participants were approached via regional Clinical Research Networks (CRNs) or based on their role in the management or provision of hospital equipment.

Ethical permission was obtained from a university departmental research ethics committee. Additional permissions were obtained as per the Health Research Authority (HRA) process for a qualitative study involving staff in the NHS (i.e., research governance was granted by the healthcare trusts that were involved in the study).

The study was based on two alternative interview scripts, so that questions could be chosen based on the circumstances of the participant (Tables 2 and 3). The scripts were created using guidance on planning semi-structured interviews in qualitative studies (Blandford, 2013). The choice of script was based on the extent to which the participant had been involved in the purchasing of infusion equipment. For script 1 (purchasers), interviews addressed 7 topics, based around the equipment lifecycle, with an emphasis on evaluating equipment usability during purchasing (Table 2). For script 2 (device users), the interviews addressed 5 topics, with less emphasis on purchasing and more on the experience of use (Table 3). This second script was created when it became clear that it would be valuable to interview equipment users who had minimal involvement in the purchasing process but could present other perspectives on the circumstances surrounding the introduction and use of equipment.

The scripts contained a default plan for the interviews, but the topics could be covered in a different order, depending on how participants responded. 
Table 1: Participants

\begin{tabular}{|c|c|c|c|c|c|}
\hline Ref & $\begin{array}{l}\text { Topic } \\
\text { guide }\end{array}$ & Reference & Organisation & Profile & $\begin{array}{l}\text { Involvement in } \\
\text { purchasing }\end{array}$ \\
\hline 1 & 1 & Ergonomics-1 & University-1 & $\begin{array}{l}\text { HCI / Ergonomics } \\
\text { researcher } \\
\text { (senior) }\end{array}$ & $\mathrm{M}$ \\
\hline 2 & 1 & Ergonomics-2 & University-1 & $\begin{array}{l}\text { HCI / Ergonomics } \\
\text { researcher } \\
\text { (senior) }\end{array}$ & $\mathrm{M}$ \\
\hline 3 & 1 & Manufacturer-1 & $\begin{array}{l}\text { Equipment } \\
\text { Manufacturer-1 }\end{array}$ & $\begin{array}{l}\text { Infusion pump } \\
\text { provider } \\
\text { (marketing) } \\
\text { (senior) }\end{array}$ & $\mathrm{H}$ \\
\hline 4 & 1 & Manufacturer-2 & $\begin{array}{l}\text { Equipment } \\
\text { Manufacturer-1 }\end{array}$ & $\begin{array}{l}\text { Infusion pump } \\
\text { provider } \\
\text { (marketing) }\end{array}$ & $\mathrm{H}$ \\
\hline 5 & 1 & $\begin{array}{l}\text { Health Service } \\
\text { Manager and } \\
\text { Accademic-1 }\end{array}$ & University-2 & $\begin{array}{l}\text { Health service } \\
\text { researcher } \\
\text { (senior) }\end{array}$ & $\mathrm{M}$ \\
\hline 6 & 1 & $\begin{array}{l}\text { Equipment Library } \\
\text { Manager-1 }\end{array}$ & Hospital-2 & Equipment library & $\mathrm{H}$ \\
\hline 7 & 1 & $\begin{array}{l}\text { Equipment Services } \\
-1\end{array}$ & Hospital-2 & $\begin{array}{l}\text { Equipment } \\
\text { services (senior) }\end{array}$ & $\mathrm{H}$ \\
\hline 8 & 1 & Device Trainer-1 & Hospital-1 & $\begin{array}{l}\text { Device trainer } \\
\text { (senior) }\end{array}$ & $\mathrm{M}$ \\
\hline 9 & 1 & $\begin{array}{l}\text { Equipment } \\
\text { Services-2 }\end{array}$ & Hospital-3 & $\begin{array}{l}\text { Equipment } \\
\text { services }\end{array}$ & $\mathrm{H}$ \\
\hline 10 & 1 & $\begin{array}{l}\text { Equipment Sevices- } \\
3\end{array}$ & Hospital-3 & $\begin{array}{l}\text { Equipment } \\
\text { services } \\
\text { (senior) } \\
\end{array}$ & $\mathrm{H}$ \\
\hline 11 & 1 & $\begin{array}{l}\text { Equipment Library } \\
\text { Manager-2 }\end{array}$ & Hospital-3 & Equipment library & $\mathrm{H}$ \\
\hline 12 & 1 & $\begin{array}{l}\text { Hospital } \\
\text { Purchasing-1 }\end{array}$ & Hospital-3 & $\begin{array}{l}\text { Purchasing } \\
\text { services (i.e. } \\
\text { tendering) } \\
\end{array}$ & $\mathrm{H}$ \\
\hline 13 & 1 & $\begin{array}{l}\text { Equipment } \\
\text { Services-4 }\end{array}$ & Hospital-4 & $\begin{array}{l}\text { Equipment } \\
\text { services } \\
\text { (senior) } \\
\end{array}$ & $\mathrm{H}$ \\
\hline 14 & 2 & Frontline-1 & Hospice-1 & $\begin{array}{l}\text { Community } \\
\text { practitioner (team } \\
\text { lead) }\end{array}$ & $\mathrm{L}$ \\
\hline 15 & 2 & Frontline -2 & Hospice-1 & Staff nurse & $\mathrm{L}$ \\
\hline 16 & 2 & Frontline -3 & Hospice-1 & District nurse & $\mathrm{L}$ \\
\hline 17 & 2 & Frontline -4 & Hospice-1 & Hospice manager & $\mathrm{L}$ \\
\hline 18 & 2 & Frontline -5 & Hospice-1 & Staff nurse & $\mathrm{L}$ \\
\hline 19 & 2 & Frontline -6 & Hospice-1 & Staff nurse & $\mathrm{L}$ \\
\hline 20 & 2 & Frontline -7 & Hospice-1 & Staff nurse & $\mathrm{L}$ \\
\hline \multicolumn{6}{|c|}{$\begin{array}{l}\text { NOTES: Frontline1-7: Worked for provider of NHS community services; Interview with } \\
\text { Ergonomics } 1 \text { and Ergonomics } 2 \text { conducted at same time. Interview with Manufacturer } 1 \text { and } \\
\text { Manufacturer } 2 \text { conducted at same time. Column "Involvement in Purchasing: L = Low: very little } \\
\text { or no involvement, } \mathrm{M}=\text { Medium: some involvement but not current, } \mathrm{H}=\text { High: recent and regular } \\
\text { involvement (at the time of the interview). }\end{array}$} \\
\hline
\end{tabular}


Table 2: Interview topics for those involved in purchasing (topic guide 1)

\begin{tabular}{|c|c|c|}
\hline Topic & Description & Mapping to aim and objectives \\
\hline $\begin{array}{l}\text { T1: Personal } \\
\text { Background }\end{array}$ & $\begin{array}{l}\text { Interviewee role and } \\
\text { responsibility. }\end{array}$ & - \\
\hline $\begin{array}{l}\text { T2: Example } \\
\text { Purchasing Project }\end{array}$ & $\begin{array}{l}\text { Example purchasing project } \\
\text { including: trigger, who was } \\
\text { involved, intended user, need } \\
\text { for new equipment. }\end{array}$ & How purchasing occurs \\
\hline T3: Process & $\begin{array}{l}\text { Awareness, interpretation, } \\
\text { utility and relevance of } \\
\text { purchasing guidelines, process } \\
\text { and authority. }\end{array}$ & How purchasing occurs \\
\hline $\begin{array}{l}\text { T4: Budget and } \\
\text { Selection }\end{array}$ & $\begin{array}{l}\text { Cost, leasing, purchasing } \\
\text { options. }\end{array}$ & $\begin{array}{l}\text { The factors that shape } \\
\text { purchasing decisions; why } \\
\text { decisions are made in the way } \\
\text { that they are }\end{array}$ \\
\hline $\begin{array}{l}\text { T5: Advice on } \\
\text { Equipment } \\
\text { Usability }\end{array}$ & $\begin{array}{l}\text { Awareness of sources of } \\
\text { support re device usability. }\end{array}$ & $\begin{array}{l}\text { The factors that shape } \\
\text { purchasing decisions; why } \\
\text { decisions are made in the way } \\
\text { that they are }\end{array}$ \\
\hline $\begin{array}{l}\text { T6: Introduction of } \\
\text { Equipment }\end{array}$ & $\begin{array}{l}\text { Phased } v \text { incremental } \\
\text { introduction, length of } \\
\text { process. }\end{array}$ & $\begin{array}{l}\text { The factors that shape } \\
\text { purchasing decisions; why } \\
\text { decisions are made in the way } \\
\text { that they are }\end{array}$ \\
\hline $\begin{array}{l}\text { T7: Agreement, } \\
\text { Reconciliation and } \\
\text { Expectations }\end{array}$ & $\begin{array}{l}\text { Reaching a consensus, trade- } \\
\text { offs, outcome v expectation, } \\
\text { what did / did not work well. }\end{array}$ & $\begin{array}{l}\text { The factors that shape } \\
\text { purchasing decisions; why } \\
\text { decisions are made in the way } \\
\text { that they are; perceptions, } \\
\text { cultures and values }\end{array}$ \\
\hline
\end{tabular}




\begin{tabular}{|c|c|c|}
\hline Topic & Description & Mapping \\
\hline $\begin{array}{l}\text { T1: Personal } \\
\text { Background }\end{array}$ & Interviewee role and responsibility. & - \\
\hline T2: Devices Used & $\begin{array}{l}\text { Example of an infusion device that } \\
\text { they used; naming conventions; } \\
\text { context of use; alternative devices. }\end{array}$ & - \\
\hline $\begin{array}{l}\text { T3: Involvement } \\
\text { in Purchasing }\end{array}$ & $\begin{array}{l}\text { Experiences of being involved in the } \\
\text { purchasing of the infusion device, } \\
\text { and/or recollection of introduction. }\end{array}$ & how purchasing occurs; \\
\hline $\begin{array}{l}\text { T4: Suitability of } \\
\text { Equipment. }\end{array}$ & $\begin{array}{l}\text { Likes / dislikes, needs, issues, } \\
\text { comparisons with other equipment. }\end{array}$ & $\begin{array}{l}\text { perceptions, cultures and } \\
\text { values }\end{array}$ \\
\hline $\begin{array}{l}\text { T5: Networks } \\
\text { and Advice }\end{array}$ & $\begin{array}{l}\text { Awareness of sources of support and } \\
\text { advice; influences on selection. }\end{array}$ & $\begin{array}{l}\text { the factors that shape } \\
\text { purchasing decisions; } \\
\text { why decisions are made in } \\
\text { the way that they are; } \\
\text { perceptions, cultures and } \\
\text { values }\end{array}$ \\
\hline
\end{tabular}

Informed consent was obtained from all participants. Where participants agreed, interviews were audio recorded and transcribed for analysis. When interviews were recorded, the audio recorder was clearly visible to participants. Alternatively, notes were taken. Pictures of equipment or purchasing documentation (e.g., questionnaires) were taken, with permission of those who were involved. These were suitably redacted (e.g. personal data removed) and used to support analysis.

In total 20 participants were interviewed, in 13 cases the interviews were audio recorded and in 7 cases the interviews were noted. Interviews ranged from 9 minutes to 2 hours in length, the average interview length was 37 minutes. This number of participants was chosen in line with established best practice (i.e. determining when saturation had occurred). In common with other studies (Guest et al., 2006) we found saturation occurred in fewer than 12 interviews.

\section{Analysis}

Audio data was transcribed; transcriptions and interview notes were loaded into NVivo (QSR International, Victoria, Australia). Data was analysed using thematic analysis, a qualitative method designed to support the identification, analysis and reporting of themes (Braun and Clarke, 2006). This method was chosen as it is independent of theory and offers a flexible and accessible approach to the rigorous analysis of qualitative data. In terms of trustworthiness (as defined by (Krefting, 1991)); the researcher established confidence by conducting interviews in a way that encouraged honesty; presenting sufficiently descriptive data to support comparison; and explaining sources of variability. 
The first author led a process of inductive coding. Over progressive interviews the set of codes was combined, revised and simplified (as in phase three of (Braun and Clarke, 2006)). Member checking occurred both during and after the interviews. For example during some interviews findings from previous interviews were checked with the interviewee. Post study a draft of the analysis was distributed to participants to check that their views were accurately represented. As part of this process, potential for variability was addressed through a consensus approach, as per recommendations in the qualitative research literature (Glaser and Strauss, 1967). As part of the analysis, codes were abstracted to determine core categories and themes. As successive transcripts were analysed, the population of codes grew to 122 . These were mapped to three themes as presented below. A mapping between the codes and the results section is provided in the supplementary data.

\section{Results}

The codes mapped to three themes: how evaluation occurs (e.g. equipment could be selected on the basis of harmonised standards); how usability is assessed (e.g. feedback could be collected from equipment users during on-site evaluations) and why equipment was replaced (e.g. equipment could be replaced as a result of national alerts). These themes were not mutually exclusive but provide an account in line with the objectives of the study. A mapping between these themes and the set of codes is provided in supplementary data.

\section{How evaluation occurs}

If a formal tendering exercise was conducted, it involved assessment based on engineering standards. These were contained within the purchasing specification. The use of standards provided a recognised way of judging the suitability of equipment, as defined by purchasing regulations. Those writing the specifications were mindful of this, in that they were working with the hospital's procurement team to ensure compliance:

"the input from procurement was also very important as to what would be appropriate, what wasn't, what we could ask for, and we couldn't ask." (8)

For usability, international standards IEC 62366 or IEC 62366-1 (application of usability engineering to medical devices) could have applied; however, there were concerns that this type of practice was not being recognised:

"well, I know there are very good companies that do spend the time, and you'd like to think they had the commercial advantage, but if their products aren't being evaluated for those advantages, then they quite possibly aren't." (1) 
Participants often referred to the need for a generic CE (Conformité Européene) mark, which is a high-level indication of compliance with the essential requirements of the European device regulations:

"It has to be CE marked, obviously, it has to be CE marked, and once it has got the CE marking you know it complies with those standards" (9)

Although the CE marking process provides assurance that the device meets European requirements (relating to performance and safety), a purchasing team would not necessarily have access to the underpinning documentation used to gain the CE mark, or the texts of the standards documents. In addition, as the process of certifying to such standards is detached from the healthcare context, it may not anticipate site-specific concerns, and it focuses on the safety of the device rather than acceptance by front line staff.

The criteria used to select equipment are therefore functional, generic in nature, focused on safety, and may not anticipate site-specific concerns. For example, frequently specified standards included ones relating to electromagnetic compatibility (EMC), electrical integrity, biocompatibility, fluid ingress, and in some cases environmental protection. These are not criteria that ensure the device is easy to use or fits with the practices in a hospital.

\section{How usability is assessed}

Purchasing practices generally included a mechanism by which local needs could be taken into account. This was because, even if the manufacturer had applied a usability engineering process, there was no guarantee that it would take account of the circumstances of the ward or department. Participants reported that purchasing involved an on-site evaluation. This could work in a number of ways; for example, staff could learn about the pumps as part of a presentation and then provide feedback:

"we had suppliers in, they gave presentations, we rated those; we had the products in, we evaluated those" (1)

Evaluation could also involve trialling equipment and completing surveys based on experiences of using it. In examples relating to the purchasing of volumetric pumps (taken from two of the four participating hospital sites), the number of staff involved was typically large (e.g. 150) and evaluation took place in a training room, away from the ward.

For these procurement exercises, surveys were scored by front line users. The scores were based on the extent to which they believed the pump met criteria relating to functionality, for example "clear display of volume infused...." This type of feedback was necessary in order to fit with other parts of the purchasing exercise (e.g. to combine it with selection on the basis of cost or technical specification).

The use of a score gave the impression of an objective process: 
"those comments would, I know they are very subjective, but we try and use them in an objective way for... that shows that exceeds a four, so we took it on board, but but but yeah it is very difficult to quantify" (13)

"So they'll bring them in for a week, work with them and then feed back to them, and put some kind of weighting on what they feel is, you know, how they feel." (6)

However, despite the numerical value and accompanying rationale giving the impression of objectivity, feedback was likely to have been subjective. For example staff may have been familiar with a particular brand, be responding from numerous perspectives or anchoring their response variably (e.g. easy to use compared with existing equipment or easy to use compared with their mobile phone?)

There was a tension between what was often seen as subjective feedback, shoehorned into a process that needed to give an impression of objectivity. For example staff were supplementing the formal evaluation criteria with their own insights, using long textual narratives, or substituting scoring criteria with verbal labels (Figure 2).

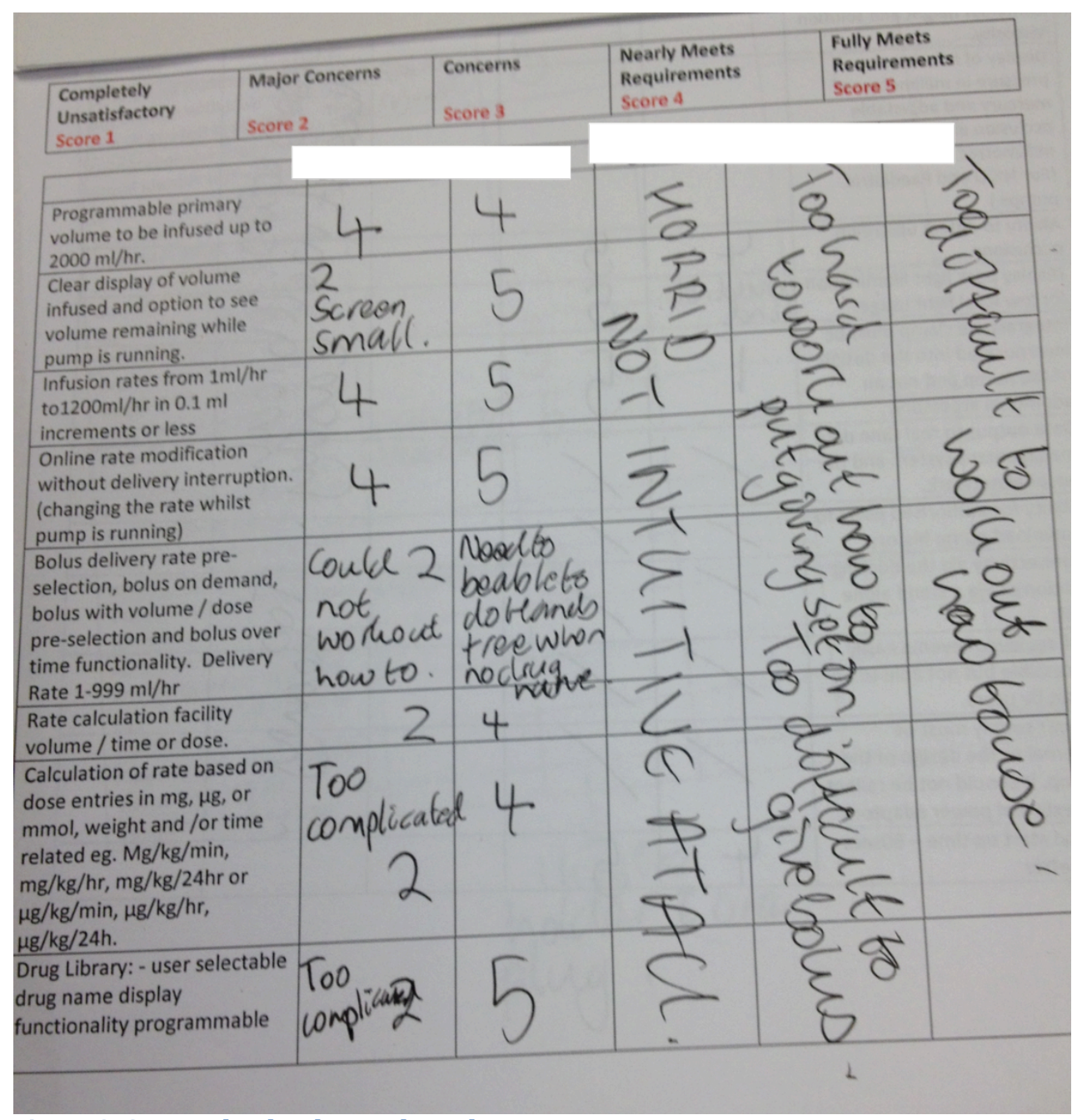

Figure 2: Survey that has been adapted 
There were also questions about who to involve when assessing usability - e.g., junior nursing staff versus senior staff - and the extent to which specialist staff should be involved (e.g. those in intensive care). Surveys had to be kept to a manageable length; this constrained the number and type of criteria that could be applied. There was a perception that some of the feedback provided during on-site evaluation was of limited value, for example:

"until you get a product out into the workplace you don't fully appreciate what are going to be the difficulties" (8)

There was also a concern that equipment purchased for one area was being trialled in another (e.g. the Intensive Treatment Unit - ITU):

"they will do a trial in ITU, which is the worst place to do a trial, because patient nurse, it's one to one, on a ward it's one to eight" (6)

There were often multiple, conflicting views on what constituted usability, many ways of defining it, and constraints in terms of how usability could be evaluated, where and by whom. What was in the interests of one part of the hospital and/or trust might not be in the interests of another. It was challenging to combine the many and varied influences during device evaluation, although some participants suggested that they were well placed to do this:

"As ergonomists, we're very good at managing people coming together, and trying to make sure that their views are represented. So, that's... you don't go into ergonomics unless you've got the ability to cope with divergent views - because you're going to get them." (1)

\section{Why equipment gets replaced}

One impetus for changing equipment (and evaluating new equipment) was the need to replace devices that were known to have poor usability. This could occur at a local level (through professional judgement), or as a result of national alerts or recalls. Due to the timing and focus of the study (on infusion device purchasing), participating hospitals had recently had experience of a national recall, which resulted in one purchasing process featuring strongly in the interviews. This featured a syringe driver that was replaced due to concerns about ease of use. This followed the release of a Rapid Response Report (RRR) from the National Patient Safety Agency (since disbanded). The report outlined concerns including the potential for confusion when setting the rate on ambulatory syringe drivers. It called for a "purchasing for safety initiative" which would address this problem:

"While the majority of syringe drivers and pumps used in healthcare have rate settings in millilitres ( $\mathrm{ml}$ ), some older types of ambulatory syringe drivers have rate settings in millimetres ( $\mathrm{mm}$ ) of syringe plunger travel. This is not intuitive for many users and not easy to check." (NPSA, 2010) 
Healthcare providers recognised this alert and initiated replacement of the equipment in question. Following the replacement, staff were generally positive about their experiences of using the new equipment; however, the situation was complicated by the limited number of pumps on the market:

"if you want a small syringe pump for this purpose there is currently one available which is really very regretful, but it's a niche market... ...So essentially we had one pump in the market, but we were able to use the tender spec to at least clarify what we required" (8)

As the replacement was unavoidable, there was little decision to be made about the interactive properties of the device. Despite purchasers going through a formal tendering process (e.g. including involvement from working groups representing front line interests), the choice of pump was a given. The user group in question was palliative care nurses. On the one hand, staff were getting a replacement which was seen to offer many advantages. On the other hand, purchasing did not involve meaningful choice.

In this case it was also apparent that many of the front line staff had not been involved in the purchasing of this device. Most thought that they should have been involved:

"I think nurses [should] have a bit of a say in it because we're the ones that sort of have the sharp end of the stick and are using them all the time. And quite often we're just told, this is what we're having and we don't get involved" (20)

Reasons for a lack of involvement could include: not being around at the time of the evaluation; the decision being driven by the "engineering department"; the hospital trust not adopting a holistic approach (and therefore not consulting with the frontline staff) or the equipment needing to be replaced in a very short timeframe.

\section{Discussion: Usability evaluation during the purchasing process}

An idealised view of the purchasing process assumes a two-way relationship between hospitals and medical device manufacturers. Hospitals shape equipment design though purchasing practice: if hospitals seek to buy equipment that is easy to use, it provides motivation for manufacturers to invest in usability and improve the design of technology from a user-centred perspective. If there is only one type of device available, or user feedback is avoided, this two-way relationship breaks down.

In our study, we found that purchasing is driven by engineering standards, and that the emphasis is on functional requirements rather than those relating to social or organisational needs. In SEIPS terms, purchasing was conducted with a focus on some parts of the work-system but not others. Changes in infusion pump technology were not "balancing" the elements of the work system. Whereas SEIPS advocates a holistic approach and multidisciplinary involvement, this study identifies practices that are closer to a Taylorist view, which 
acknowledges the need to get the right tool for the job but also seeks to standardise work and diminish the autonomy of the worker.

An alternative view, that takes into account social circumstances, is Barley's (1986) account of "technology as an occasion for structuring," in which technology is treated as a social object rather than a physical one and is conceptualized as a process rather than an entity. According to this perspective, true evaluation can only occur in an organisational setting (or proxy of one), as technology alters institutional roles and patterns of interaction. For example, the introduction of a new type of syringe driver might require new operating procedures, which could in turn impact on broader practices such as prescribing.

This highlights a need for tools that allow those involved in equipment evaluation to conduct an assessment not only of the suitability of the equipment, but of the combination of equipment, staff and organisational circumstances, before and after the replacement. This assessment would be shared across members of the organization and serve to strengthen links, should there be a need for follow-up support and advice. In this way, the pump replacement would act as more than a replacement of technology: it would support a refinement of the organisation surrounding the technology.

Although there was an acknowledgement of the need to factor in the social circumstances of technology use (of which usability was a component), the formal purchasing process made this very challenging. This is not the first time that such a tension has been observed. For example, Pollock and Williams (2007) describe the purchasing processes as "dragging" the choices surrounding the procurement from an informal domain to a formal one. In acknowledging the role for cultural sociological accounts, they suggest a "grey area" that opens up between rationalist and sociological approaches. They identify a need for tools to bridge this gulf. There is a tension between a view of the purchasing process as expressing formal and objective criteria as defined by a statement of economic, managerial and engineering intent (e.g. rigid adherence to a tendering specification) and a view that good purchasing decisions cannot be detached from the organization setting.

Although collectives such as purchasing committees are working together in selecting a pump for purchasing, the overall method is systematic and functional. For example, the group focuses on forming a technical specification. Buying is characterised by adherence to this specification, fixed rules and a hierarchy of authority. On the one hand, the formal approach provides a decision that is accountable and objective; on the other hand, it can be insensitive to the organisational context and fail to truly represent the needs of users.

There is a need to revisit what the purchasing process means. The current situation is reminiscent of the waterfall process of software development (Benington, 1983), where those writing a specification need to produce the most detail early on in the process, when they know the least. As many of our participants observed, there is no way of knowing the true relationship between technology and the organization until after equipment has been deployed. A 
different approach is required where requirements are developed iteratively, amongst teams. For example the inclusion of HF / usability specialists on purchasing committees and use of systems models such as SEIPS could help broaden the focus and move beyond a purely functionalist agenda.

In this case additional tools are required to empower groups to understand how equipment is really used in practice, facilitating a closer match to the circumstances of use. There are numerous techniques that can be used to build a better understanding, sensitise to multiple perspectives, and represent informal accounts (see Table 4). They are exemplified by the approach of soft systems methodology (Checkland, 1981), which utilises rich pictures (pictorial summaries of findings from interviews, reports etc.), and has been applied in various public sector improvement projects (Flood and Carson, 1993).

The process might also be facilitated by tools that can be applied with flexibility and rigour and represent multiple perspectives. One example is multi-attribute utility models that formalise the tradeoffs between product characteristics such as cost and safety. The technique was originally applied in the 1970's and has been used in many domains, including inventory ordering for blood banks (Kenney, 1972). In applying this technique, there is scope to consider a broader range of subjective criteria, which would address some of the issues identified in this study. 
Table 4: Examples of approaches that can represent 'social' requirements

\begin{tabular}{|c|c|c|c|}
\hline Approach & Addresses & Resources & $\begin{array}{l}\text { Comment / } \\
\text { limitations }\end{array}$ \\
\hline $\begin{array}{l}\text { SEIPS; Consideration } \\
\text { of the sociotechnical } \\
\text { system }\end{array}$ & $\begin{array}{l}\text { Focus on single } \\
\text { parts of the } \\
\text { work-system / } \\
\text { evaluation in } \\
\text { isolation }\end{array}$ & $\begin{array}{l}\text { http://cqpi.wisc.edu/seips- } \\
\text { main.htm }\end{array}$ & $\begin{array}{l}\text { Need to consider } \\
\text { how modelling } \\
\text { efforts can be } \\
\text { integrated with } \\
\text { purchasing process }\end{array}$ \\
\hline $\begin{array}{l}\text { Including HF / HCI } \\
\text { professionals on } \\
\text { purchasing } \\
\text { committees }\end{array}$ & $\begin{array}{l}\text { Lack of } \\
\text { awareness of HF } \\
\text { / HCI }\end{array}$ & NA & $\begin{array}{l}\text { Need to make HCI } \\
\text { knowledge and } \\
\text { process available } \\
\text { and effective at the } \\
\text { right time }\end{array}$ \\
\hline $\begin{array}{l}\text { Develop models to } \\
\text { combine objective } \\
\text { and subjective } \\
\text { influences }\end{array}$ & $\begin{array}{l}\text { Functional } \\
\text { approach }\end{array}$ & $\begin{array}{l}\text { Multi-attribute utility theory } \\
\text { e.g., (Pecchia et al., 2013) . }\end{array}$ & $\begin{array}{l}\text { Trade-offs } \\
\text { regarding safety } \\
\text { may be } \\
\text { unacceptable }\end{array}$ \\
\hline $\begin{array}{l}\text { Use tools that } \\
\text { support a statement } \\
\text { of social } \\
\text { requirements }\end{array}$ & $\begin{array}{l}\text { Limited input } \\
\text { regarding } \\
\text { usability }\end{array}$ & $\begin{array}{l}\text { Soft Systems Methodology } \\
\text { (Checkland, 1981). }\end{array}$ & $\begin{array}{l}\text { Subjective } \\
\text { influences may not } \\
\text { be an acceptable } \\
\text { input }\end{array}$ \\
\hline $\begin{array}{l}\text { Illustrate how } \\
\text { multiple } \\
\text { requirements inform } \\
\text { the selection process } \\
\text { and illustrate trade- } \\
\text { offs }\end{array}$ & $\begin{array}{l}\text { Rationale for } \\
\text { decision unclear, } \\
\text { not accessible to } \\
\text { a range of staff }\end{array}$ & $\begin{array}{l}\text { Design Rationale. (Moran and } \\
\text { Carroll, 1996). }\end{array}$ & $\begin{array}{l}\text { May not scale to } \\
\text { broader system } \\
\text { models }\end{array}$ \\
\hline $\begin{array}{l}\text { Increase the fidelity / } \\
\text { realism of the } \\
\text { context used to } \\
\text { conduct the } \\
\text { evaluation }\end{array}$ & $\begin{array}{l}\text { Wrong } \\
\text { assumptions }\end{array}$ & $\begin{array}{l}\text { Simulation (Lamsdale et al., } \\
\text { 2005) }\end{array}$ & $\begin{array}{l}\text { Limits to fidelity of } \\
\text { simulation }\end{array}$ \\
\hline
\end{tabular}

\section{Limitations}

Limitations to the study include issues of generalizability, in terms of generalising across purchasing contexts and activities. Because we were aiming to understand the realities of practice without bringing preconceptions of what we would find, no a priori framework was used to generate the interview topics. Given the complexity and variability of purchasing practices across health service organisations, we cannot be certain that we have identified the full range of practices. We aimed to achieve coverage by working with individuals across eight organisations, including four hospitals and a hospice. Findings were broadly similar across these different organisations; however, there might have been different findings for other combinations of device, context and condition. Further work could study how consistent the purchasing process is and address these issues of generalizability. At the time of conducting the work it was difficult to recruit those who had direct experience of infusion device purchasing and had knowledge and experience in HF / HCI, reflecting the limited number of people with this dual expertise. Given this limitation future work could engage purchasers with mock purchasing scenarios and then allow them to be consulted with a human factors focus. It could elicit if and how human factors issues affect their decision-making. 


\section{Conclusion}

This study has highlighted the need to supplement the current formal process with greater consideration of the social circumstances surrounding use of technology. We have proposed approaches that can be applied with flexibility and rigour, to support systems thinking and represent multiple perspectives.

In shifting the emphasis in purchasing, from one where the solution is determined through rigid specification to one that is sensitive to user needs at a local level, there is potential for future purchasing to leverage the benefits of diversity in practice, rather than seeking to overcome them (e.g. encouraging consultation and discussion to inform change, rather than attempting to shoehorn user views into an inflexible framework). In this case, staff would involve themselves in a co-evolution of equipment and practices, aligned with the broader management and functioning of the health service, rather than having solutions imposed on them.

\section{Conflict of Interest Statement}

Employment: The first author is currently employed by product and service design innovation consultancy PDD Group Ltd.

\section{Acknowledgments}

We would like to thank all of those who have been involved in the research presented in this paper, including all study participants; Professor Michael Harrison for his comments on an earlier version of the manuscript; and the research nurse who helped arrange some of the interviews. This study was conducted within the CHI+MED project, supported by the UK Engineering and Physical Sciences Research Council [EP/G059063/1].

\section{References}

AAMI/FDA, 2010. Infusing Patients Safely: Priority Issues from the AAMI/FDA Infusion Device Summit Washington DC.

Barley, S.R., 1986. Technology as an occasion for structuring: evidence from observations of CT scanners and the social order of radiology departments. Adm Sci Q 31, 78-108.

Benington, H.D., 1983. Production of Large Computer Programs. Annals of the History of Computing 5, 350-361.

Blandford, A., 2013. Semi-structured qualitative studies in HCI, in: Soegaard, M., Dam, R.F. (Eds.), The Encyclopedia of Human-Computer Interaction. The Interaction Design Foundation, Aarhus, Denmark.

Blandford, A., Furniss, D., Vincent, C., 2014. Patient safety and interactive medical devices: Realigning work as imagined and work as done. Clinical Risk. 
Braun, V., Clarke, V., 2006. Using thematic analysis in psychology. Qualitative Research in Psychology 3, 77-101.

Carayon, P., 2009. The Balance Theory and the Work System Model ... Twenty Years Later. International Journal of Human-Computer Interaction 25, 313-327.

Carayon, P., Hundt, A.S., Wetterneck, T.B., 2010. Nurses' acceptance of Smart IV pump technology. International journal of medical informatics 79, 401-411.

Carayon, P., Schoofs Hundt, A., Karsh, B.-T., Gurses, A.P., Alvarado, C.J., Smith, M., Flatley Brennan, P., 2006. Work system design for patient safety: the SEIPS model. Quality and Safety in Health Care 15, i50-i58.

Carayon, P., Smith, M.J., 2000. Work organization and ergonomics. Appl Ergon 31, 649662.

Carayon, P., Wetterneck, T.B., Rivera-Rodriguez, A.J., Hundt, A.S., Hoonakker, P., Holden, R., Gurses, A.P., 2014. Human factors systems approach to healthcare quality and patient safety. Appl Ergon 45, 14-25.

Cassano-Piché, A., Cafazzo, J.A., Chagpar, A., Easty, A.C., 2010. Choosing Safer Medical Technologies: How Human Factors Methods Can Help in the Procurement Process. Biomedical Instrumentation \& Technology 44, 49-56.

Checkland, P., 1981. Systems thinking, systems practice. Wiley, Chichester.

Cook, T.M., 2012. Non-Luer connectors: are we nearly there yet? Anaesthesia 67, 784792.

Cook, T.M., Pandit, J.P., Wilkes, A.R., 2012. Introduction and evaluation of new airway devices: Current issues. Trends in Anaesthesia and Critical Care 2, 264-268.

FDA, 2016. Applying Human Factors and Usability Testing to Medical Devices FDA, Silver Spinrg, MD.

Flood, R.L., Carson, E.R., 1993. Dealing with complexity : an introduction to the theory and application of systems science, 2nd ed. ed. Plenum, New York ; London.

Ford, J.L., Phillips, P., 2008. How to evaluate sharp safety-engineered devices. Nursing times 104, 42-45.

Freemantle, A., Clark, D., Crosby, V., 2011. Safer ambulatory syringe drivers: experiences of one acute hospital trust. International journal of palliative nursing 17, 86-91.

Gandillon, R., 2013. Infusion pump reliability and usability: Veteran's health administration examines differences between manufacturers. Journal of Clinical Engineering 38, 27-31.

Ginsburg, G., 2005. Human factors engineering: a tool for medical device evaluation in hospital procurement decision-making. Journal of Biomedical Informatics 38, 213-219.

Glaser, B., Strauss, A., 1967. The Discovery of Grounded Theory Aldine Publishing Company, Hawthorne, NY.

Gosbee, J., Klancher, J., Arnecke, B., Wurster, H., Scanlon, M., 2001. The Role of Usability Testing in Healthcare Organizations. Proceedings of the Human Factors and Ergonomics Society Annual Meeting 45, 1308-1311.

Guest, G., Bunce, A., Johnson, L., 2006. How Many Interviews Are Enough?: An Experiment with Data Saturation and Variability. Field Methods 18, 59-82.

Hinrichs, S., 2009. A Systems Approach to Improving Patient Safety through Medical Device Purchasing, Engineering. Cambridge, Cambridge.

Hussain, Z., Taylor, W.A., 2007. Evaluating the behaviour of information systems developers: the relevance and utility of paradigms. Behaviour and Information Technology 26, 221-236. 
IEC, 2015. Medical devices -- Part 1: Application of usability engineering to medical devices, 62366-1. International Electrotechnical Commission, Geneva.

Johnson, T.R., Zhang, J., Patel, V.L., Keselman, A., Tang, X., Brixey, J.J., Paige, D., Turley, J.P., 2005. The Role of Patient Safety in the Device Purchasing Process, in: Henriksen, K., Battles, J.B., Marks, E.S., Lewin, D.I. (Eds.), Advances in Patient Safety: From Research to Implementation (Volume 1: Research Findings). Agency for Healthcare Research and Quality (US), Rockville (MD).

Kenney, R.L., 1972. An illustrated procedure for assessing multiattributed utility functions. Sloan management review 14, 37-50.

Keselman, A., Patel, V.L., Johnson, T.R., Zhang, J., 2003. Institutional decision-making to select patient care devices: identifying venues to promote patient safety. Journal of Biomedical Informatics 36, 31-44.

Keselman, A., Tang, X., Patel, V.L., Johnson, T.R., Zhang, J., 2004. Institutional decisionmaking for medical device purchasing: evaluating patient safety. Stud Health Technol Inform 107, 1357-1361.

Kinsella, S.M., 2013. The shock of the 'Nuer': the UK experience with new non-Luer neuraxial equipment and implications for obstetric anaesthesia. International journal of obstetric anesthesia 22, 1-5.

Kinsella, S.M., Goswami, A., Laxton, C., Kirkham, L., Wharton, N., Bowen, M., 2012. A clinical evaluation of four non-Luer spinal needle and syringe systems. Anaesthesia 67, 1217-1224.

Koppel, R., Wetterneck, T., Telles, J.L., Karsh, B.T., 2008. Workarounds to barcode medication administration systems: their occurrences, causes, and threats to patient safety. J Am Med Inform Assoc 15, 408-423.

Krefting, L., 1991. Rigor in Qualitative Research: The Assessment of Trustworthiness. American Journal of Occupational Therapy 45, 214-222.

Lamsdale, A., Chisholm, S., Gagnon, R., Davies, J., Caird, J., 2005. A Usability Evaluation of an Infusion Pump by Nurses Using a Patient Simulator. Proceedings of the Human Factors and Ergonomics Society Annual Meeting 49, 1024-1028.

Lee, P.T., Thompson, F., Thimbleby, H., 2012. Analysis of infusion pump error logs and their significance for health care. British Journal of Nursing 21, S12-S20.

Liddell, A., Adshead, S., Burgess, E., 2008. Technology in the NHS: Transforming the patient's experience of care. The King's Fund, London.

Maguire, M., 2001. Context of Use within usability activities. International Journal of Human-Computer Studies 55, 453-483.

Money, A.G., Barnett, J., Kuljis, J., Craven, M.P., Martin, J.L., Young, T., 2011. The role of the user within the medical device design and development process: medical device manufacturers' perspectives. Bmc Medical Informatics and Decision Making 11.

Moran, T.P., Carroll, J.M., 1996. Design rationale : concepts, techniques and use. Erlbaum, Mahwah, N.J. ; [Hove].

Namshirin, P., Ibey, A., Lamsdale, A., 2011. Applying a multidisciplinary approach to the selection, evaluation, and acquisition of smart infusion pumps. Journal of Medical and Biological Engineering 31, 93-98.

Nemeth, C., Nunnally, M., Bitan, Y., Nunnally, S., Cook, R.I., 2009. Between choice and chance: the role of human factors in acute care equipment decisions. J Patient Saf 5, 114-121.

Nemeth, C.P., Brown, J., Crandall, B., Fallon, C., 2014. The mixed blessings of smart infusion devices and health care IT. Mil Med 179, 4-10. 
NPSA, 2010. Rapid Response Report: Safer Ambulatory Syringe Drivers in: NPSA (Ed.). NPSA, London.

Patterson, E.S., Doebbeling, B.N., Fung, C.H., Militello, L., Anders, S., Asch, S.M., 2005. Identifying barriers to the effective use of clinical reminders: bootstrapping multiple methods. Journal of Biomedical Informatics 38, 189-199.

Pecchia, L., Martin, J.L., Ragozzino, A., Vanzanella, C., Scognamiglio, A., Mirarchi, L., Morgan, S.P., 2013. User needs elicitation via analytic hierarchy process (AHP). A case study on a Computed Tomography (CT) scanner. BMC Med Inform Decis Mak 13, 2.

Phillips, W., Knight, L., Caldwell, N., Warrington, J., 2007. Policy through procurementThe introduction of digital signal process (DSP) hearing aids into the English NHS. Health Policy 80, 77-85.

Pollock, N., Williams, R., 2007. Technology choice and its performance: Towards a sociology of software package procurement. Information and Organization 17, 131-161.

Rajkomar, A., Blandford, A., 2012. Understanding infusion administration in the ICU through Distributed Cognition. J Biomed Inform 45, 580-590.

Saleem, J.J., Patterson, E.S., Militello, L., Render, M.L., Orshansky, G., Asch, S.M., 2005. Exploring barriers and facilitators to the use of computerized clinical reminders. J Am Med Inform Assoc 12, 438-447.

Schraagen, J.M., Verhoeven, F., 2013. Methods for studying medical device technology and practitioner cognition: The case of user-interface issues with infusion pumps. Journal of Biomedical Informatics 46, 181-195.

Smith, M.J., Carayon, P., 1989. A balance theory of job design for stress reduction. International Journal of Industrial Ergonomics 4, 67-79.

Trbovich, P.L., Cafazzo, J.A., Easty, A.C., 2011. Implementation and optimization of smart infusion systems: Are we reaping the safety benefits? J Healthc Qual.

Turley, J.P., Johnson, T.R., Smith, D.P., Zhang, J., Brixey, J.J., 2006. Operating manualbased usability evaluation of medical devices: an effective patient safety screening method. Jt Comm J Qual Patient Saf 32, 214-220.

Zhang, J.J., Johnson, T.R., Patel, V.L., Paige, D.L., Kubose, T., 2003. Using usability heuristics to evaluate patient safety of medical devices. Journal of Biomedical Informatics 36, 23-30. 


\section{Supplementary data}

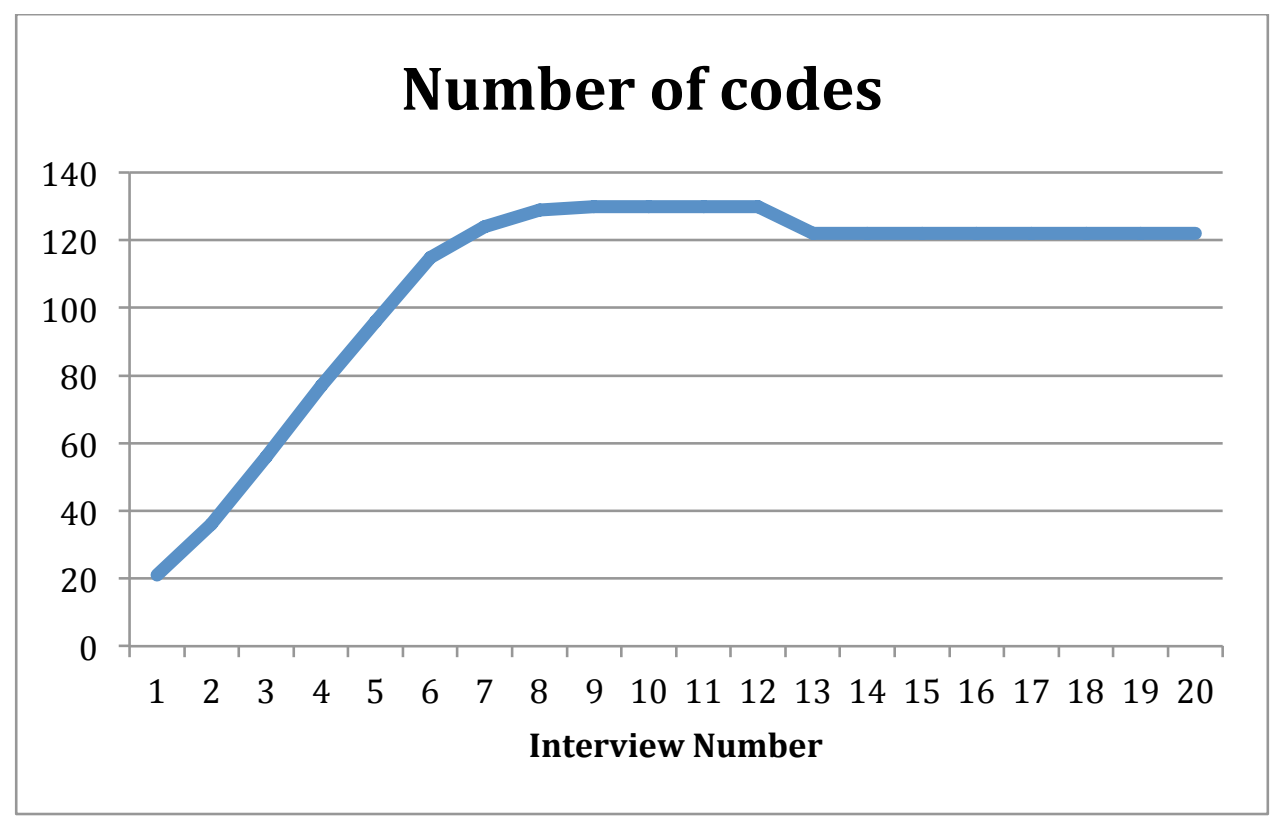

Codes ordered by frequency of occurrence. Under "category", we list the themes; some codes are not reported in this paper.

\begin{tabular}{|l|l|}
\hline Name of code & Category \\
\hline Whole life and systems view & How evaluation occurs \\
\hline Blur between health service and commercial support & - \\
\hline Equipment replacement & $\begin{array}{l}\text { Why equipment gets } \\
\text { replaced }\end{array}$ \\
\hline Hospital organization & General background \\
\hline Shortcomings of equipment & $\begin{array}{l}\text { Why equipment gets } \\
\text { replaced }\end{array}$ \\
\hline Collectivism or winner takes all & - \\
\hline Complexity and scale & General background \\
\hline Integration of equipment & - \\
\hline Purchasing process & How evaluation occurs \\
\hline Rules, regulations and policy & How evaluation occurs \\
\hline Safety & $\begin{array}{l}\text { Why equipment gets } \\
\text { replaced }\end{array}$ \\
\hline Standardization of equipment types & $\begin{array}{l}\text { Why equipment gets } \\
\text { replaced }\end{array}$ \\
\hline Substance of user input & $\begin{array}{l}\text { How usability is } \\
\text { assessed }\end{array}$ \\
\hline Discrepancies around cost and transparency of cost & - \\
\hline $\begin{array}{l}\text { Front line interest and involvement in purchasing } \\
\text { decisions }\end{array}$ & How evaluation occurs \\
\hline Management of equipment & - \\
\hline Savings and economy & - \\
\hline
\end{tabular}




\begin{tabular}{|l|l|}
\hline Name of code & Category \\
\hline Training & - \\
\hline Availability of equipment & $\begin{array}{l}\text { Why equipment gets } \\
\text { replaced }\end{array}$ \\
\hline Big bang v phased & - \\
\hline Clinical engagement & $\begin{array}{l}\text { How usability is } \\
\text { assessed }\end{array}$ \\
\hline $\begin{array}{l}\text { Conflict between stakeholders and need to involve } \\
\text { them }\end{array}$ & $\begin{array}{l}\text { How usability is } \\
\text { assessed }\end{array}$ \\
\hline Dose Error Reduction Systems (DERS) & - \\
\hline Evaluation metric & How evaluation occurs \\
\hline Focus is broader than usability & How usability is \\
& assessed \\
\hline Going through the motions & - \\
\hline Liability and litigation & - \\
\hline Tradeoff & How usability is \\
& assessed \\
\hline Unexpected outcome & - \\
\hline Bias & - \\
\hline Blur between technical and clinical evaluation & How usability is \\
& assessed \\
\hline Capacity & - \\
\hline Conflicts of interest & - \\
\hline Cost benefit analysis & - \\
\hline Disconnects & - \\
\hline Fixed timescales & $\begin{array}{l}\text { Why equipment gets } \\
\text { replaced }\end{array}$ \\
\hline Hands are tied & - \\
\hline Hierarchy & - \\
\hline Making cost transparent & - \\
\hline Senior versus junior feedback & How usability is \\
& assessed \\
\hline Servicing & - \\
\hline Unusual process & - \\
\hline Bureaucratic process & - \\
\hline Capital v revenue & - \\
\hline Common language or lack of common language & - \\
\hline Configuration & - \\
\hline Customization & - \\
\hline Device risk levels & - \\
\hline Disconnect between purchasing and the front line & How usability is \\
& assessed \\
\hline Drug device combinations & - \\
\hline Dynamic process & - \\
\hline Education & - \\
\hline & \\
\hline
\end{tabular}




\begin{tabular}{|l|l|}
\hline Name of code & Category \\
\hline $\begin{array}{l}\text { Equipment often purchased based on feedback from } \\
\text { intensive care }\end{array}$ & $\begin{array}{l}\text { How usability is } \\
\text { assessed }\end{array}$ \\
\hline Forced decision & $\begin{array}{l}\text { Why equipment gets } \\
\text { replaced }\end{array}$ \\
\hline Hospital management & $\begin{array}{l}\text { How usability is } \\
\text { assessed }\end{array}$ \\
\hline Human Factors as education & Discussion \\
\hline Incidents & - \\
\hline Lack of evidence & - \\
\hline Leasing versus buying & - \\
\hline Level playing field and fair play & - \\
\hline Match between pump and practice & How usability is \\
& assessed \\
\hline Obvious decision & Why equipment gets \\
& replaced \\
\hline Project management & - \\
\hline Regret & - \\
\hline Scenarios & - \\
\hline Sharing knowledge & - \\
\hline Workarounds & - \\
\hline Accidental overdose & - \\
\hline Being seen to put the user first & - \\
\hline Blur between equipment providers & - \\
\hline Catch 22 & - \\
\hline Charity & - \\
\hline Confusion & - \\
\hline Denial & - \\
\hline Destructive testing & - \\
\hline $\begin{array}{l}\text { Differences between volumetric pumps and syringe } \\
\text { drivers }\end{array}$ & - \\
\hline Difficulty of change and time of change & - \\
\hline Failure to learn & - \\
\hline Future proofing & - \\
\hline How open & - \\
\hline In situ updates & - \\
\hline Innovation & - \\
\hline Internal v external process & - \\
\hline Internal versus external purchasing process & - \\
\hline International differences & - \\
\hline Isolating parts of the hospital & - \\
\hline Lean and sig sigma & - \\
\hline Lock-ins & - \\
\hline Management of transition & - \\
\hline Manufacturer bias & - \\
\hline & - \\
\hline
\end{tabular}




\begin{tabular}{|l|l|}
\hline Name of code & Category \\
\hline Move towards private provision & - \\
\hline Nature of evidence & - \\
\hline Need for usability evaluation & - \\
\hline No need to overcomplicate things & - \\
\hline Patient first & - \\
\hline Positive versus negative framing & - \\
\hline Predictability of failure & - \\
\hline Quality of tendering process & - \\
\hline Reconciliation of equipment & - \\
\hline Reducing redundant equipment & - \\
\hline Relationships & - \\
\hline Replication of effort & - \\
\hline Resilience & - \\
\hline Scaling of process depending on device type & - \\
\hline Senior buy in & - \\
\hline Service rather than device & - \\
\hline Show and tell & - \\
\hline Simulation & - \\
\hline Standardization of the UI & - \\
\hline Supply chain & - \\
\hline Technical spec v usability & - \\
\hline Time to develop products & - \\
\hline Training as a way to address safety concerns & - \\
\hline Unintended delivery & - \\
\hline Utilization & - \\
\hline Variability of users & - \\
\hline Variations in practice & - \\
\hline What the pumps are being used for & - \\
\hline Wider political changes & - \\
\hline Cost of fragmentation & - \\
\hline Preventative measures & - \\
\hline Reducing length of stay & - \\
\hline & \\
\hline
\end{tabular}

